\title{
HUBUNGAN STATUS PERIODONTAL DAN DERAJAT REGULASI GULA DARAH PASIEN DIABETES MELITUS DI RUMAH SAKIT UMUM PUSAT PROF DR. R. D. KANDOU MANADO
}

\author{
${ }^{1}$ Stephanie F. Emor \\ ${ }^{2}$ Karel Pandelaki \\ ${ }^{3}$ Aurelia S. R. Supit
}
${ }^{1}$ Kandidat Skripsi Program Studi Pendidikan Dokter Gigi Fakultas Kedokteran
${ }^{2}$ Bagian Penyakit Dalam Fakultas Kedokteran
${ }^{3}$ Program Studi Pendidikan Dokter Gigi Fakultas Kedokteran
Universitas Sam Ratulangi Manado
Email: stephanieemor@icloud.com

\begin{abstract}
Diabetes mellitus (DM) is a disorder characterized by hyperglycemia and impaired metabolism of carbohydrates, fats, and proteins. These are caused by insulin deficiency, relative or absolute. Diabetes mellitus is a long-term chronic disease with a risk of the occurence of diabetic complications, such as oral diabetic. The study aimed to analyze the relationship between periodontal status and the degree of blood sugar regulation in diabetic patients in Prof. Dr. R. D. Kandou Hospital Manado. Data were obtained from the Endocrine clinic of Prof. Dr. R. D. Kandou Hospital. This was a descriptive analytical study with a cross sectional approach. Samples consisted of 37 patients (total sampling) aged 20-60 years. The analytic methods used in this study was the chi-square test (univariate and bivariate). Periodontal pocket depths were clinically examined. The results showed that there was no healthy periodontal state among diabetic patients. Uncontrolled diabetic patients with poor HbA1c (17 patients, 46\%) had bad periodontal status. The chi-square test showed that there was a significant relationship between periodontal status and the degree of blood sugar regulation in diabetic patients $(p<0.05)$. Conclusion: There was a significant relationship between periodontal status and the degree of blood sugar regulation in diabetic patients. Keywords: periodontal status, diabetes mellitus, degree of regulation blood sugar.
\end{abstract}

\begin{abstract}
Abstrak: Diabetes melitus (DM) adalah kelainan yang ditandai hiperglikemia dan gangguan metabolisme karbohidrat, lemak, dan protein yang disebabkan oleh kekurangan hormon insulin secara relatif maupun absolut. DM merupakan penyakit kronis yang bila diabaikan dapat terjadi komplikasi diabetic, antara lain oral diabetic. Penelitian ini bertujuan untuk menganalisis hubungan status periodontal dan derajat regulasi gula darah pasien diabetes melitus di RSUP Prof. Dr. R. D. Kandou Manado. Pengumpulan data dilakukan di Poliklinik Endokrin RSUP Prof. Dr. R. D. Kandou. Penelitian ini bersifat deskriptif analitik dengan pendekatan potong lintang. Besar sampel sebanyak 37 orang (total sampling) usia 20-60 tahun. Analisis data secara univariat dan bivariat (uji chi-square). Pemeriksaan kedalaman poket periodontal dilakukan terhadap subjek penelitian. Hasil penelitian menunjukkan tidak adanya status periodontal yang sehat pada pasien DM. Pasien DM dengan HbA1c yang buruk memiliki status periodontal yang buruk pula yaitu sebanyak 17 pasien (46\%). Berdasarkan hasil uji chi-square terdapat hubungan bermakna antara status periodontal dan derajat regulasi gula darah $(\mathrm{p}<0,05)$. Simpulan: Terdapat hubungan bermakna antara status periodontal dan derajat regulasi gula darah pasien diabetes melitus.
\end{abstract}

Kata kunci: status periodontal, diabetes melitus, derajat regulasi gula darah 
Diabetes melitus (DM) merupakan penyakit metabolik dengan karakteristik hiperglikemia yang terjadi karena kelainan sekresi insulin, kerja insulin atau keduanya. Menurut World Health Organization (WHO) DM merupakan suatu kumpulan masalah anatomik dan kimiawi akibat dari sejumlah faktor di mana didapat defisiensi insulin absolut atau relatif dan gangguan fungsi insulin. ${ }^{1} \mathrm{DM}$ merupakan salah satu masalah kesehatan yang masih dihadapi Indonesia hingga saat ini. Departemen Kesehatan RI dan Badan Kesehatan Dunia atau WHO memprediksikan kenaikan jumlah penderita DM di Indonesia dari 8,4 juta pada tahun 2000 meningkat menjadi 21,3 juta pada tahun $2030 .^{2}$

Derajat regulasi gula darah ialah derajat kontrol gula darah dalam hal ini adalah kontrol gula darah HbA1c karena sampai sekarang ini tes HbA1c merupakan cara yang paling baik untuk mengetahui apakah gula darah dalam batas kontrol yang baik atau buruk. ${ }^{3}$

HbA1c adalah suatu molekul hemoglobin yang terikat dengan glukosa. Sel darah merah dapat hidup selama 8-12 minggu. ${ }^{4}$ Oleh karena itu pengukuran HbA1c pada tes laboratorium dapat mengukur kadar glukosa darah secara ratarata selama 2-3 bulan terakhir. ${ }^{5}$

Salah satu komplikasi DM yang cukup serius di bidang kedokteran gigi ialah oral diabetic, yang meliputi mulut kering, gingiva mudah berdarah (gingivitis), kalkulus, resorbsi tulang alveolaris, periodontitis dan lain sebagainya. ${ }^{6}$ Dari sekian banyak komplikasi yang terjadi, periodontitis merupakan komplikasi yang paling sering terjadi pada penderita DM dengan tingkat prevalensi yang tinggi hingga mencapai angka 75\%. Penderita DM mempunyai kecenderungan untuk menderita periodontitis lebih besar dibandingkan dengan yang tidak menderita DM. Hal ini disebabkan karena adanya perubahan pada pembuluh darah, gangguan fungsi neutrofil, sintesis kolagen, faktor mikrobiotik, dan predisposisi genetik. ${ }^{7}$

Berdasarkan hal tersebut maka penulis meneliti hubungan status periodontal dengan derajat regulasi gula darah pasien DM di Poliklinik Endokrin Rumah Sakit Umum Pusat Prof. Dr. R. D. Kandou Manado.

\section{BAHAN DAN METODE PENELITIAN}

Rancangan penelitian yang digunakan deskriptif analitik dengan pendekatan cross sectional. Penelitian dilaksanakan di Poliklinik Endokrin RSUP Prof. Dr. R. D. Kandou Manado. Populasi penelitian ini ialah pasien DM di Poliklinik Endokrin. Sampel diperoleh dengan menggunakan teknik total sampling, yaitu seluruh pasien di Poliklinik Endokrin Rumah Sakit Umum Pusat Prof. Dr. R. D. Kandou yang datang pada bulan Agustus-September 2014 berjumlah 37 pasien.

Kriteria inklusi yaitu penderita DM yang memiliki catatan medik kontrol gula darah HbA1c, berusia 20-60 Tahun, bersedia menjadi subjek penelitian dengan mengisi formulir dan menandatangani informed consent, bersikap kooperatif, masih memiliki gigi yang dibutuhkan untuk pengukuran status periodontal, dan tidak sedang dalam terapi radiasi. Kriteria eksklusi yaitu gigi berjejal kelainan pernapasan (bibir/rahang), mengonsumsi makanan lunak sebelum pemeriksaan dilakukan, serta mengalami iatrogenik dentistry, trauma oklusi, kelainan genetik, atau defisiensi nutrisi.

Instrumen penelitian dalam penelitian ini ialah lembar pemeriksaan. Alat yang digunakan ialah probe periodontal dengan ujung berbentuk bola berdiameter $0,5 \mathrm{~mm}$, area berwarna hitam sebagai skala berada pada daerah 3,5-5,5 mm (periodontal probe WHO), kaca mulut no 4, Nier beken. Bahan yang digunakan alkohol 70\%, cairan antiseptik, kapas, masker, sarung tangan, air untuk berkumur.

Pengumpulan data dengan pengambilan data primer dan sekunder. Data Primer berupa diambil langsung dari pemeriksaan status periodontal pada masing-masing pasien dengan menggunakan probe periodontal. Data sekunder (nama, umur, kadar gula darah dan jenis kelamin) diambil dari Poliklinik Endokrin 
RSUP Prof. Dr. R. D. Kandou Manado. Pengolahan data berdasarkan distribusi frekuensi keadaan status periodontal pasien yang diukur dengan menggunakan CPITN dan HbA1c sebagai parameter kontrol gula darah. Data dianalisis berdasarkan hasil pengolahan data yang telah disajikan dalam bentuk tabel distribusi frekuensi. Analisis data digunakan analisis data univariat dan bivariat. Analisis univariat data diolah dengan sistem Statistical Product and Service Solution (SPSS) versi 20. Analisis bivariat menggunakan Uji Chi Square. ${ }^{8}$ Dasar pengambilan keputusan untuk menerima atau menolak hipotesis berdasarkan tingkat signifikan (nilai $p$ ). Bila p >0,05, maka hipotesis penelitian ditolak, sedangkan bila $\mathrm{p}<0,05$, maka hipotesis penelitian diterima.

\section{HASIL PENELITIAN}

\section{Karakteristik subjek penelitian}

Karakteristik yang diamati pada responden meliputi usia, jenis kelamin, dan lamanya menderita DM. Pada penelitian ini responden yang memenuhi kriteria berjumlah 37 pasien dengan rentang usia 20-60 tahun yang dijabarkan dalam Tabel $1-5$.

\section{Analisis Univariat}

Pada Tabel 1 dapat dilihat bahwa pasien di Poliklinik Endokrin RSUP Prof. Dr. R. D. Kandou Manado terdiri dari pasien laki-laki sebanyak 13 orang $(35,1 \%)$ dan pasien perempuan yaitu sebanyak 24 orang (64,9\%).

Tabel 1. Distribusi responden berdasarkan jenis kelamin

\begin{tabular}{ccc}
\hline $\begin{array}{c}\text { Jenis } \\
\text { kelamin }\end{array}$ & Frekuensi (n) & $\%$ \\
\hline Laki-laki & 13 & 35,1 \\
Perempuan & 24 & 64,9 \\
Total & 37 & 100 \\
\hline
\end{tabular}

Pada Tabel 2 dapat dilihat bahwa karakteristik umur responden dibagi menjadi 4 kelompok. Responden pada kelompok umur 26-35 tahun sebanyak 2 pasien (5,4\%), kelompok umur 36-45 tahun sebanyak 8 pasien (21,7\%), kelompok umur 46-55 tahun sebanyak 15 pasien (40,5\%), dan kelompok umur 56-65 tahun sebanyak 12 pasien (32,4\%).

Tabel 2. Distribusi responden berdasarkan usia

\begin{tabular}{ccc}
\hline $\begin{array}{c}\text { Usia } \\
\text { (tahun) }\end{array}$ & $\begin{array}{c}\text { Frekuensi } \\
\text { (n) }\end{array}$ & $\%$ \\
\hline $26-35$ & 2 & 5,4 \\
$36-45$ & 8 & 21,7 \\
$46-55$ & 15 & 40,5 \\
$56-65$ & 12 & 32,4 \\
Total & 37 & 100 \\
\hline
\end{tabular}

Pada Tabel 3 dapat diketahui bahwa lama menderita DM paling terbesar selama 6-10 tahun yaitu sebanyak 10 pasien (27,0 $\%$, sedangkan selama 21-25 tahun sebanyak 2 pasien (5,4\%) merupakan lama menderita DM terkecil.

Tabel 3. Distribusi responden berdasarkan lama menderita DM

\begin{tabular}{ccc}
\hline $\begin{array}{c}\text { Lama menderita DM } \\
\text { (tahun) }\end{array}$ & $\begin{array}{c}\text { Frekuensi } \\
\text { (n) }\end{array}$ & (\%) \\
\hline $1-5$ & 9 & 24,3 \\
$6-10$ & 10 & 27,0 \\
$11-15$ & 7 & 18,9 \\
$16-20$ & 9 & 24,3 \\
$21-25$ & 2 & 5,4 \\
Total & 37 & 100 \\
\hline
\end{tabular}

Tabel 4 menunjukkan tidak ada pasien DM yang memiliki status periodontal yang baik (0\%). Pasien DM dengan status periodontal sedang 16 pasien (43,2\%) dan yang dengan status periodontal buruk 21 pasien (56,8 \%).

Tabel. 4 Distribusi responden berdasarkan status periodontal

\begin{tabular}{ccc}
\hline $\begin{array}{c}\text { Status } \\
\text { Periodontal }\end{array}$ & Frekuensi (n) & (\%) \\
\hline Baik & 0 & 0 \\
Sedang & 16 & 43,2 \\
Buruk & 21 & 56,8 \\
Total & 37 & 100 \\
\hline
\end{tabular}


Tabel 5 menunjukkan bahwa pasien DM yang memiliki kontrol gula darah HbA1c tingkat baik sebanyak 4 pasien (10,8\%), tingkat sedang sebanyak 16 pasien $(43,2 \%)$, dan tingkat buruk sebanyak 17 pasien (45,9 \%).

Tabel 5. Distribusi responden berdasarkan tingkat HbA1c

\begin{tabular}{ccc}
\hline Tingkat & Frekuensi (n) & $\%$ \\
HbA1c & 4 & 10,8 \\
\hline Baik & 16 & 43,2 \\
Sedang & 17 & 45,9 \\
Buruk & 37 & 100 \\
Total & \\
\hline
\end{tabular}

\section{Analisis Bivariat}

Data Tabel 6 menunjukan bahwa 17 pasien (46\%) dengan status periodontal buruk semuanya memiliki derajat regulasi gula darah HbA1c yang buruk.

Tabel 6. Uji chi square antara status periodontal dengan derajat regulasi gula darah pasien DM

Tingkat HbA1c

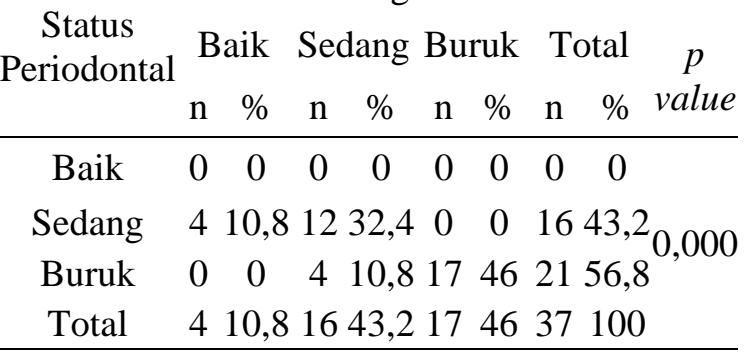

\section{BAHASAN}

Distribusi responden berdasarkan jenis kelamin berjumlah 37 pasien dengan jumlah pasien perempuan lebih banyak dengan 24 pasien (64,9\%), dibandingkan laki-laki yang hanya 13 pasien $(35,1 \%)$ (Tabel 7). Penelitian Maidiana et al. tahun 2012 menunjukkan pula bahwa pasien perempuan lebih banyak melakukan kontrol gula darah HbA1c dibandingkan laki-laki. ${ }^{9}$ Pada penelitian ini, pasien perempuan lebih banyak menjadi sampel penelitian karena pasien perempuan lebih banyak memeriksakan diri di Poliklinik Endokrin RSUP Prof. Dr. R. D. Kandou Manado.
Distribusi responden berdasarkan usia dapat dilihat pada Tabel 8. Mayoritas sampel yang diperoleh berumur 46-55 sebanyak 15 pasien (40,5\%). Berdasarkan penelitian Nandya dan Agustina tahun 2013 DM biasanya ditemukan pada pasien berusia $>30$ tahun dan paling banyak ditemukan pada rentang usia 50-70 tahun. ${ }^{10}$

Distribusi pasien berdasarkan lamanya menderita DM (Tabel 9), jumlah tertinggi $>10$ tahun sebesar 27,0\%. Penelitian Hidayati tahun 2008 di RSUP Dr. Soetomo Surabaya menjelaskan bahwa keparahan periodontitis bukan dipengaruhi oleh lamanya menderita tapi lebih dipengaruhi oleh kadar gula darah pasien DM sendiri. Hidayati berpendapat bahwa meskipun lama menderita DM tapi kadar gula darah penderita DM tetap terkontrol dengan baik maka tingkat keparahan panyakit periodontal juga akan lebih baik. ${ }^{11}$ Pada penelitian ini juga terlihat bahwa lama menderita DM tidak menjamin baik buruknya jaringan periodontal tapi hanya tergantung pada derajat kontrol gula darah.

Status periodontal pasien DM di Poliklinik Endokrin RSUP Prof. DR. R. D. Kandou Manado (Tabel 10) menunjukkan bahwa tidak ada satupun pasien DM yang memiliki status periodontal baik atau normal Status periodontal sedang ditemukan pada 16 pasien (43,2\%) dan status periodontal yang buruk 21 pasien (56,8\%). Berdasarkan hasil penelitian Pranckeviciene et al., tidak ada satupun pasien DM yang memiliki jaringan periodontal normal. ${ }^{12}$ Pada penderita DM, dengan meningkatnya kadar glukosa dalam darah dan cairan gingival berarti juga mengubah lingkungan mikroflora dan menginduksi perubahan bakteri secara kualitatif. Perubahan tersebut mengarah pada penyakit periodontal yang berat.

Kontrol gula darah HbA1c pasien DM digolongkan pada 3 tingkatan: baik, sedang, dan buruk. Distribusi responden berdasarkan tingkat HbA1c (Tabel 11) paling tinggi ialah tingkat HbA1c buruk yaitu 17 pasien (45,9\%). Berdasarkan penelitian yang dilakukan oleh Ayu dan 
Indrirawati (2004), penderita DM dengan kontrol gula darah buruk atau tidak terkontrol lebih banyak disertai penyakit periodontal yang parah dibandingkan dengan DM terkontrol. ${ }^{13}$ Pasien DM dengan kontrol gula darah buruk disertai oleh beberapa perubahan pada periodonsium berpotensi dan berperan dalam terjadinya periodontitis kronis.

Tabel 12 menunjukkan tidak ditemukan status periodontal yang sehat, dan pasien DM yang memiliki derajat regulasi gula darah HbA1c yang buruk memiliki status periodontal yang buruk pula sebanyak 17 pasien (46\%). Berdasarkan hasil uji chisquare nilai $p=0,000$ (probabilitas $<0,05$ ) maka Ho ditolak dan $\mathrm{H}_{\mathrm{I}}$ diterima. Nilai $p=$ 0,000 menunjukkan hubungan bermakna antara status periodontal dan derajat regulasi gula darah pasien DM. Hal ini disebabkan oleh karena DM dapat meningkatkan risiko kerusakan jaringan periodontal yang berlanjut. Perkembangan periodontitis lebih besar pada pasien DM dengan kontrol glikemik buruk disbandingkan pasien DM terkendali baik. Kontrol glikemik buruk pada pasien DM juga telah dikaitkan dengan peningkatan risiko progresif dari kehilangan perlekatan jaringan periodontal dan tulang alveolar. ${ }^{14}$

Menurut Matthews DC, pasien DM tidak terkontrol harus lebih sering dievaluasi, terutama bila pasien telah mengalami penyakit periodontal. Ship JA menyatakan bahwa DM tidak terkontrol memiliki risiko komplikasi oral yang lebih tinggi sehingga membutuhkan waktu tambahan dalam penanganan periodontal dan terapi antibiotik. ${ }^{15}$

Pada pasien DM, meningkatnya kadar glukosa dalam darah dan cairan gingival juga merubah lingkungan mikroflora dan menginduksi perubahan bakteri secara kualitatif. Perubahan tersebut mengarah pada penyakit periodontal berat, dan dapat teramati pada pasien DM dengan kontrol buruk. Berkaitan dengan jaringan periodontal, hiperglikemia kronik akan meningkatkan aktivitas kolagenase dan menurunkan sintesis kolagen. Enzim kolagenase menguraikan kolagen sehingga ligamen periodontal rusak, kehilangan perlekatan jaringan periodontal dan tulang alveolar, dan gigi menjadi goyah. Jaringan periodontal akan menjadi kuat kembali bila DM diobati dengan baik. ${ }^{16}$

Terdapat perubahan fungsi sel seperti neutrofil, monosit dan makrofag pada DM. Proses kemotaksis dan fagositosis neutrofil sering terganggu. Sel-sel ini merupakan garis pertama pertahanan tubuh, dan penghambatan fungsi sel-sel tersebut dapat mencegah penghancuran bakteri dalam poket periodontal sehingga meningkatkan kerusakan periodontal. ${ }^{14}$

\section{SIMPULAN}

Berdasarkan hasil penelitian dapat disimpulkan bahwa terdapat hubungan bermakna antara status periodontal dan derajat regulasi gula darah pasien DM.

\section{SARAN}

1. Pasien DM diharapkan melakukan pemeriksaan rongga mulut agar dapat menjaga kesehatan rongga mulut dan kontrol gula darah HbA1c.

2. Bagi rumah sakit diharapkan dapat memberlakukan pemeriksaan HbA1c pada pasien DM secara rutin atau kebijakan lainnya yang dapat membantu terkontrolnya tingkat HbA1c pasien DM.

3. Bagi tenaga medis diharapkan dapat memberikan informasi mengenai pemeriksaan HbA1c sebagai upaya pengendalian glikemik jangka panjang yang akurat dan merujuk ke poliklinik gigi agar pasien dapat memeriksakan kesehatan gigi dan mulutnya.

\section{DAFTAR PUSTAKA}

1. Soegondo S, Sarih DP, Suyono S. Ilmu penyakit dalam. Ed 5. Interna Publishing: 2009. h.1877-80.

2. Sulistria YM. Tingkat self care pasien rawat jalan diabetes mellitus tipe 2 di puskesmas Kalirungkut Surabaya. Jurnal Ilmiah. Vol 2(2). Surabaya: 2013. h.1-11.

3. Florkowski C. HbA1c as a diagnostic test for diabetes mellitus-reviewing the 
evidence. Clin Biochem Rev. 2013;34:75-83.

4. World Health Organization. Use of glycated haemoglobin (HbA1c) in the diagnosis of diabetes mellitus. Abbreviated report of WHO consultation. Geneva: WHO.2011.p.125.

5. Braatvedt GD, Cundy $T$, Crooke $M$, Florkowski C, Mann Jl, Lunt $\mathrm{H}$, et al. Understanding the new $\mathrm{HbA} 1 \mathrm{c}$ unit for the diagnosis in type 2 diabetes. N Z Med J 2012;125:70-80.

6. Respati TN, Iwanda. Hubungan diabaetes mellitus dengan karies gigi. Artikel ilmiah [serial online] 2006; [15 halaman]. Semarang: UNDIP Diunduh dari: URL: http://www.eprints.undip.ac.id/.

7. Stones HH, Farmer ED, Lawton FE. Stone's oral and dental diseases. Livingstone: Michigan University, 1966; p. 869.

8. Suharsimi A. Prosedur penelitian suatu pendekatan praktik. Jakarta: Rineka Cipta, 2010; p. 389-91.

9. Maidina TS, Djallalluddin, Yasmina A. Hubungan kadar HbA1c dengan kejadian kaki diabetik pada psien diabetes mellitus di RSUD Ulin Banjarmasin April-September 2012. Berkala Kedokteran. 2013;9(2):211-7.

10.Nandya ME, Agustina FE. Status kesehatan jaringan periodontal pada psien diabetes mellitus tipe 2 dibandingkan dengan pasien non diabetes mellitus berdasarkan GPI. [serial online].[cited 2012 Agu 08]. Available from URL:
Journal.unair.ac.id/.../e-...

11.Hidayati S, Mu'afiro A. Suwito J. Analisis faktor yang berhubungan dengan tingkat keparahan periodontitis pada penderita DM tipe II di poli diabetes RSU Dr. Soetomo Surabaya. [serial online]. 2008 [cited 2012 Aug 08]; 10(2): 51-4. Available from URL: isjd.pdii.;ipi.go.id/admin/jurnal/10208 4954.pdf.

12.Pranckevicene A, Siudikiene J, Ostrauskas R, Machiulskiene V. Keparahan dari penyakit periodontal pada pasien diabetes mellitus dengan tipe diabetesnya. Department of dental and oral pathology. Lithuainian Universitas of health Science, Eiveniu 2,50009-Kaunas, Lithuania. p. 8-22.

13.Indrawati T, Lely AS. Pengaruh kadar glukosa darah yang terkontrol terhadap penurunan derajat kegoyahan gigi penderita diabetes mellitus di RS Persahabatan Jakarta. J Media Litbang Kesehatan. 2004. p. 38-43.

14. Mealey BL. Periodontal disease and diabetes mellitus. A two-way-sheet. J Am Dent Assoc. 2006;137(Suppl_2):26S-31S.

15.Debora C, Matthews DDS. The Relationship Between Diabetes and Periodontal Disease. J Can Dent Assoc. 2002;68(3):161-4.

16. Lingen MW, Kumar V. Head and neck. In: Kumar V, Abbas AK, Fausto N, eds. Robbins \& Cotran Pathologic Basis of Disease (7th ed). Philadelphia: Elsevier, 2004; p.773. 